\title{
The impact of constructive operating lease capitalisation on key accounting ratios
}

\author{
Vivien Beattie, Keith Edwards and Alan Goodacre*
}

\begin{abstract}
Current UK lease accounting regulation does not require operating leases to be capitalised in the accounts of lessees, although this is likely to change with the publication of FRS 5. This study conducts a prospective analysis of the effects of such a change. The potential magnitude of the impact of lease capitalisation upon individual users' decisions, market valuations, company cash flows, and managers' behaviour can be indicated by the effect on key accounting ratios, which are employed in decision-making and in financial contracts. The capitalised value of operating leases is estimated using a method similar to that suggested by Imhoff, Lipe and Wright (1991), adapted for the UK accounting and tax environment, and developed to incorporate company-specific assumptions. Results for 1994 for a random sample of 300 listed UK companies show that, on average, the unrecorded long-term liability represented $39 \%$ of reported long-term debt, while the unrecorded asset represented $6 \%$ of total assets. Capitalisation had a significant impact (at the 1\% level) on six of the nine selected ratios (profit margin, return on assets, asset turnover, and three measures of gearing). Moreover, the Spearman rank correlation between each ratio before and after capitalisation revealed that the ranking of companies changed markedly for gearing measures in particular. There were significant inter-industry variations, with the services sector experiencing the greatest impact. An analysis of the impact of capitalisation over the five-year period from 1990 to 1994 showed that capitalisation had the greatest impact during the trough of the recession. Results were shown to be robust with respect to key assumptions of the capitalisation method. These findings contribute to the assessment of the economic consequences of a policy change requiring operating lease capitalisation. Significant changes in the magnitude of key accounting ratios and a major shift in company performance rankings suggest that interested parties' decisions and company cash flows are likely to be affected.
\end{abstract}

\section{Introduction}

The use of leasing as a form of asset financing has been growing worldwide during the past twenty years. In the UK, leasing represented $15.8 \%$ of the total investment in equipment by 1994 (Finance and Leasing Association, 1994). Although published information does not permit the calculation of a comprehensive lease ratio (capitalised value of leased assets to total assets), a crude indication of the overall significance of leasing across asset categories can be obtained from the ratio of the annual lease payment commitment to total assets. An analysis of data extracted from the Extel Company Analysis database for the population of UK listed companies $(\mathrm{n}=2,288)$ shows this 'annual' lease ratio to be $0.76 \%$ in 1994 . Moreover, the figures

*The authors are, respectively, professor, former research student, and senior lecturer at the University of Stirling. Correspondence should be addressed to Dr. Alan Goodacre, Department of Accounting. Finance and Law, University of Stirling, Stirling, UK, FK9 4LA. Tel. 0044-1786 467291; Fax 0044-1786 467308; e-mail Alan.Goodacre@stir.ac.uk. The financial support of the Research Board of the Institute of Chartered Accountants in England and Wales is gratefully acknowledged. The authors also wish to thank two anonymous reviewers for their extremely helpful comments on an earlier draft of this paper, which was first submitted in June 1997; the final version was accepted in May 1998. for operating and finance leases are $0.74 \%$ and $0.04 \%$, respectively, indicating that the annual operating lease commitments are 18 times that of finance leases.

Prior to 1984, UK leasing growth could be attributed to two main factors. First, the availability of $100 \%$ first year allowances meant that lessees with insufficient profits to utilise this allowance through asset purchase could instead lease the asset and pay rentals which reflected the tax saving made by the lessor. Second, the off-balance sheet nature of lease transactions was attractive since gearing levels are not adversely affected. The Finance Act 1984 provided for the gradual removal of first year allowances, and SSAP 21 required the capitalisation of finance leases by lessees from 1987. Despite these events, leasing in the UK has not declined, the level remaining approximately constant since 1984 (Finance and Leasing Association, various years). In particular, this may be due to the design of lease contracts which avoid being classified as finance leases. However, there are clearly also other significant advantages (of both a general and a company-specific nature) from leasing.

The US was the first country to adopt a lease accounting standard, SFAS 13 (FASB, 1976). Prior to this, most lease payments were simply 
charged to the profit and loss account as incurred. Leases were classified into two types, those which transfer to the lessee substantially all the risks and rewards of ownership (known as capital or finance leases) and those which do not (known as operating leases). SFAS 13 required capital leases to be capitalised, i.e. a liability is created in the lessee's balance sheet reflecting the lessee's future obligations under the lease, and a corresponding asset is created reflecting the lessee's rights in the asset. The concepts and definitions of lease accounting introduced by SFAS 13 were substantially adopted by many countries (including the UK, Canada, Australia, and New Zealand) and the IASC, although the US standard is the most prescriptive. In the UK, the growth in leasing from the mid1970s and the collapse of Courtline were contributory factors in the move towards lease regulation. SSAP 21 Accounting for leases and hire purchase contracts was introduced in 1984 and its full lessee provisions were effective from 1987 (ASC, 1984).

Standard-setters in the UK, US, Australia, and New Zealand, together with the IASC, have recently published a discussion paper: Accounting for leases: a new approach, which proposes that all leases be capitalised (McGregor, 1996). It is likely that a new UK lease accounting standard will soon be introduced based upon this proposal, since this would resolve the current conflict which exists between SSAP 21 and FRS 5 Reporting the substance of transactions (ASB, 1994). FRS 5 (para. 4) defines liabilities as 'an entity's obligations to transfer economic benefits as a result of past transactions or events', from which it appears to follow that all ongoing lease contracts give rise to liabilities and should, therefore, be reflected in the balance sheet. In recognition of this conflict, FRS 5 states that the standard that contains the more specific provisions relating to a transaction should be applied; in the case of leases, this is in general SSAP 21.

Given the economic significance of leasing, a change in lease regulation which requires the capitalisation of operating leases is likely to have a significant impact on the accounting numbers of many companies. This could impact, in turn, upon a wide variety of individual users' decisions (e.g. credit rating, loan assessment, risk evaluation), aggregate investor decisions (i.e. share prices), company cash flows (via contracts based on accounting numbers which apply 'rolling' GAAP), and managers' behaviour (i.e. financing decisions and earnings management). See, for example, Taylor and Turley (1985), Garrod (1989), Citron (1992), and Breton and Taffler (1995) for relevant UK studies. The impact of such a regulatory change on the accounting numbers is captured effectively by observing the change in key accounting ratios. Financial analysis textbooks in both the UK and the US indicate that ratios are used widely by in- vestment analysts and loan officers as decision tools (Foster, 1986; Bouwman et al., 1987; Cohen et al, 1987; Holmes and Sugden, 1995; and Rees, 1995). Moreover, a UK questionnaire survey has shown that $70 \%$ of analysts use financial ratios extensively in forecasting earnings (Arnold and Moizer, 1984), while a US survey found that gearing was crucial to loan officers' lending decisions (Gibson, 1983).

Thus, the principal objective of this paper is to provide evidence which will assist in assessing the economic consequences of a change in the regulation of lease accounting, by estimating the impact on key accounting ratios of the requirement to capitalise all non-cancellable operating leases by lessee companies. This paper, therefore, represents policy-relevant, ex ante research in support of the standard-setting process of the type advocated by Schipper (1994). To achieve this objective, a comprehensive database of operating lease information is created from published corporate annual reports, and operating leases are capitalised using an amended version of the method proposed by Imhoff, Lipe and Wright (1991) (hereafter ILW).

The remainder of this paper is structured as follows. Section two provides a summary of the accounting regulation salient to leases, reviews the existing evidence concerning the impact of lease capitalisation on accounting ratios, and the ILW capitalisation procedure. The third section describes the methods used. Results are presented and discussed in section four. The final section summarises and concludes the paper.

\section{Literature review}

\subsection{Lease regulation}

In general, the trend in lease accounting regulation has been from the footnote disclosure of obligations to the capitalisation of these obligations (and the related asset) in the balance sheet. A summary of the regulatory pronouncements in the UK and elsewhere which have affected lease accounting in the UK is given in Figure 1. This figure shows that the classification rules for finance leases are more stringent under SFAS 13 than SSAP 21. It is therefore to be expected that, ceteris paribus, operating leases will represent a larger proportion of leases in the UK than in the US, since preparers of accounts may prefer leases to be classified as operating due to the more favourable effect on gearing ratios, in particular. Any further regulatory change requiring the capitalisation of operating leases will, consequently, have a greater impact upon the accounting numbers and key accounting ratios in the UK.

A recent analysis of UK financial reporting practice with respect to leases shows that considerable variation exists, particularly in disclosure lev- 


\section{Figure 1}

Chronology and content of regulatory pronouncements affecting lease accounting in the UK

US

ASR 147 (SEC, 1973)

Required footnote disclosures in 10-K reports.

Opinion 13 (APB, 1973)

Suggested the disclosure of the present value of gross minimum rental commitments.

SFAS 13 (FASB, 1976)

Effective for leases entered into on or after 1 January 1977. Capital lease defined as one under which any of the following four conditions is met:

- the present value at the beginning of the lease term of the payments not representing executory costs paid by the lessor equals or exceeds $90 \%$ of the fair value of the leased asset;

- the lease transfers ownership of the asset to the lessee by the end of the lease term;

- the lease contains a bargain purchase price (i.e., an option to buy);

- the lease is equal to $75 \%$ or more of the estimated economic life of the leased asset.

Leases which do not satisfy any of these conditions are classed as operating leases.

Required the capitalisation of capital leases by lessee with operating lease payments reported as a profit and loss account charge, and disclosure of total minimum future payments under operating leases with remaining terms of more than one year (reported separately for each of the next five years and combined thereafter).

\section{UK}

ED 29 (ASC, 1981)

Proposed the capitalisation of finance leases by lessors.

SSAP 21 (ASC, 1984)

Effective for lessors for accounting periods beginning on or after 1 July 1984; full provisions effective for lessees for accounting periods beginning on or after 1 July 1987, with disclosure requirements effective for accounting periods beginning on or after 1 July 1984. Finance lease defined as one which in substance passes over to the lessee substantially all the risks and rewards of ownership. A present value test is provided to aid classification: a lease is presumed to be a finance lease if the present value at the beginning of the lease term of the minimum lease payments, discounted at the interest rate implicit in the lease, amounts to substantially all (normally $90 \%$ or more) of the fair value of the leased asset (the ' $90 \%$ test').

Other leases are classed as operating leases.

Required the capitalisation of finance leases by lessees, with operating lease payments charged to the profit and loss account on a straight line basis over the lease term (analysed between hire of plant and machinery and other operating leases). Also required the disclosure of next year's minimum future payments under operating leases, analysed according to the period in which the annual commitment expires (those expiring next year, within the second to fifth year inclusive, and over five years from the balance sheet date), further analysed between land and buildings and other operating leases.

TR 664 (ICAEW, 1987)

Encourages the consideration of aspects of the lease other than the $90 \%$ test in classifying leases.

FRS 5 (ASB, 1994)

Requires the consideration of all aspects of transactions in determining the appropriate accounting treatment, and so would appear to require recognition of assets and liabilities to the extent that risks and rewards have been transferred. The apparent conflict between SSAP 21 and FRS 5 is resolved by an explanation that the standard containing the more specific provisions should be applied and that, in general, these are contained in SSAP 21.

\section{International}

\section{IAS 17 (IASC, 1982)}

Effective for accounting periods beginning on or after 1 January 1984. This standard is general in approach and its disclosure requirements are less detailed than for either SFAS 13 or SSAP 21. Compliance with SSAP 21 ensures compliance with IAS 17 in all material respects. 
els (Loveday, 1995). First, some companies charge operating lease rentals to the profit and loss account as incurred, contrary to SSAP 21 , while others do not state the basis used. Second, the operating lease rental asset categories stipulated by SSAP 21 are not always followed. Third, many companies do not disclose either the method used to allocate finance lease rentals between capital and interest or the basis on which leased assets are depreciated. Finally, in response to FRS 5, five FTSE 100 companies have chosen to reclassify operating leases as finance leases (Company Reporting, 1995).

\subsection{The impact of lease capitalisation on accounting ratios}

The first published study of the impact of lease capitalisation on accounting ratios was conducted by Nelson (1963), who examined the effect of lease capitalisation on the debt-equity ratio of eleven US companies. He found a significant change in the rankings of the companies after capitalisation compared to before capitalisation. Fifteen ratios were calculated for each company, and in $56 \%$ of cases a change in rank of two or more places occurred. Ashton (1985) extended Nelson's study in a UK context, recognising that the impact of lease capitalisation will affect five accounting numbers: interest charges, depreciation, fixed assets, accumulated depreciation, and debt. The resulting impact on key ratios will depend upon the relationship between the capital element in the lease rentals (which rises over time) and the depreciation charged on the leased asset. This depends, in turn, upon the asset's estimated life, the primary lease term, and the method of depreciation.

Ashton identified two scenarios. First, where the primary lease term is sufficiently shorter than the estimated life of the asset, he argued that depreciation would generally be less than the capital repayment element of the lease rentals, and so reported profits and capital employed would initially rise. However, this will only occur if depreciation is based on the estimated life of the asset. If, as SSAP 21 requires for finance leases, it is based on the shorter of the asset life and the lease period, then depreciation will generally exceed the capital repayment element of the lease rentals, and reported profits will initially fall. This also applies for Ashton's second scenario, where the primary lease term equals the asset life (1985: 233-234).

Ashton (1985) estimated the effect of finance lease capitalisation on six ratios for 23 companies. He found only the individual reported results for the gearing ratio to be affected significantly. All Spearman rank correlations between pre- and post-capitalisation ratios were greater than or equal to 0.90 , from which he concluded that inter- firm comparisons of performance would not be affected significantly by capitalisation. He cautioned, however, that his sample was small and potentially unrepresentative.

More recently, in a pioneering study, ILW (1991) developed a method for the constructive capitalisation of operating leases, used to estimate the impact of operating lease capitalisation on two ratios (return on assets and debt to equity) for 14 US companies (seven matched industry pairs, selected to represent high and low operating lease use). They find material differences in the ratios for both 'high' and 'low' lessees, concluding that operating lease capitalisation can materially affect inter-firm comparisons of key financial statement ratios. (Subsequent to the completion of this study, ILW published a paper which explored the income effects (Imhoff, Lipe and Wright, 1997).)

The key features of these three studies, each of which is based on a small, non-random sample, are summarised in Table 1. The impact of operating lease capitalisation does appear to alter key ratios significantly in the US, although the impact on ranking was not explored explicitly. The impact of operating lease capitalisation has, to date, not been explored in the UK setting.

\subsection{ILW capitalisation procedure}

The basis of the procedure developed by ILW (1991) for the US reporting environment is the schedule of minimum total future operating lease payments disclosed by US companies in a note to the financial statements. The total commitment is analysed by time period (amounts payable in each of the next five years and after five years). In this paper, ILW focus on the balance sheet effects of operating lease capitalisation, assuming that the income statement effects are negligible.

The accuracy of the procedure is limited by the availability of public domain data. Thus, based upon a detailed examination of only one company (McDonalds Corporation), ILW develop the following six uniform assumptions for general application. Estimation of the present value of the unrecorded lease liability depends critically upon assumptions regarding the appropriate interest rate and the average remaining life of leases where this life exceeds five years. First, ILW assume that the appropriate interest rate is $10 \%$ for each company. This is conservative, since the historical interest rate on McDonalds' secured long-term debt, based on the 1988 debt footnote is $9 \%$. Second, ILW assume that the average remaining life of the operating leases is 15 years since, in McDonalds case, this figure produces a smoothly decreasing schedule of minimum future cash flows as at 1988 , which is the typical pattern. Third, the assumption of year-end cash flows provides a further built-in conservative bias. 


\section{Table 1}

Summary of empirical studies of the impact of lease capitalisation on accounting ratios

\begin{tabular}{lcccc}
$\begin{array}{l}\text { Study } \\
\text { Nelson }\end{array}$ & $\begin{array}{c}\text { Country } \\
(1963)\end{array}$ & $\begin{array}{c}\text { Sample size and } \\
\text { type }\end{array}$ & Ratios examined & \multicolumn{1}{c}{ Findings } \\
& & 11 companies & $\begin{array}{l}15 \text { ratios, including } \\
\text { debt/equity }\end{array}$ & $\begin{array}{l}\text { Some ratios quite } \\
\text { substantially affected, } \\
\text { producing markedly } \\
\text { different company } \\
\text { rankings }\end{array}$
\end{tabular}

Conclusions

Inter-firm comparisons of some ratios inaccurate and misleading without lease capitalisation

$\begin{array}{ll}\text { Ashton UK } & 23 \text { companies from } \\ \text { (1985) } & 300 \text { in the Survey } \\ & \text { of Published } \\ & \text { Accounts 1983/84 } \\ \text { which gave } & \text { sufficient } \\ & \text { information to } \\ & \text { isolate effect of } \\ & \text { finance lease } \\ & \text { capitalisation }\end{array}$

Return on Difference between shareholders' funds; pre- and postreturn on capital capitalisation ratios employed; profit significantly different margin; asset for only gearing turnover; interest (significance level not cover; gearing reported); Spearman rank correlation between pre- and postcapitalisation ratios lowest for gearing at 0.90 , which is still 'high'

$\begin{array}{ll}\begin{array}{l}\text { Imhoff, US } \\ \text { Lipe and }\end{array} & \begin{array}{l}\text { Seven pairs of } \\ \text { companies from } \\ \text { Wright }\end{array} \\ \begin{array}{l}\text { different industries, } \\ \text { (1991) }\end{array} & \begin{array}{l}\text { matched on size } \\ \text { but with different } \\ \text { operating lease use }\end{array}\end{array}$

Inter-firm comparisons of performance not significantly affected by finance lease capitalisation

\author{
Return on assets Average decrease in \\ (ROA); debt/equity ROA: \\ (D/E) \\ - 'high' lessees $34 \%$ \\ - 'low' lessees $10 \%$ \\ Average increase in $\mathrm{D} /$ \\ E: \\ - 'high' lessees 191\% \\ - 'low' lessees $47 \%$
}

Operating lease capitalisation can materially affect inter-firm comparisons of key financial ratios
Estimation of the present value of the unrecorded lease asset requires further assumptions to be made regarding the weighted average total lease life and the depreciation method that would be used. Figure 2 demonstrates that the relationship between asset value and lease liability depends on the proportion of the lease which has expired. The model assumes that (i) straight line depreciation is used for all assets, (ii) the capitalised asset and the capitalised liability both equal $100 \%$ of the present value of the future lease payments at the beginning of the lease, and (iii) the capitalised asset and the capitalised liability both equal zero at the end of the lease. ILW also implicitly assume a standard, simple, lease payment profile with no initial costs, nor reverse premiums, and no contingent rental payments.

The ratio of asset to liability (asset proportion) can be expressed as:

$$
\frac{\mathrm{PV}_{\mathrm{A}}}{\mathrm{PV}_{\mathrm{L}}}=\frac{\mathrm{RL}}{\mathrm{TL}} \times \frac{\mathrm{PVAF}_{\mathrm{r} \%, \mathrm{TL}}}{\mathrm{PVAF}_{\mathrm{r} \%, \mathrm{RL}}}
$$

where:

$\mathrm{PV}_{\mathrm{A}}=$ present value of unrecorded asset,

$\mathrm{PV}_{\mathrm{L}}=$ present value of unrecorded liability,

$\mathrm{RL}=$ remaining lease life,

$\mathrm{TL}=$ total lease life, and

$\mathrm{PVAF}_{\mathrm{r} \%, \mathrm{n}}=$ present value annuity factor for $£ 1$ at $\mathrm{r} \%$ for $\mathrm{n}$ years.

ILW calculate the asset proportion for 105 different combinations of the three variables: total lease life (years) $=10,15,20,25$, and 30 ; interest rate $=8 \%, 10 \%$ and $12 \%$; and total lease life expired $(\%)=20,30,40,50,60,70$, and 80 . They show that the asset proportion lies between $60 \%$ 


\section{Figure 2}

Relation between the unrecorded operating lease asset and unrecorded operating lease liability

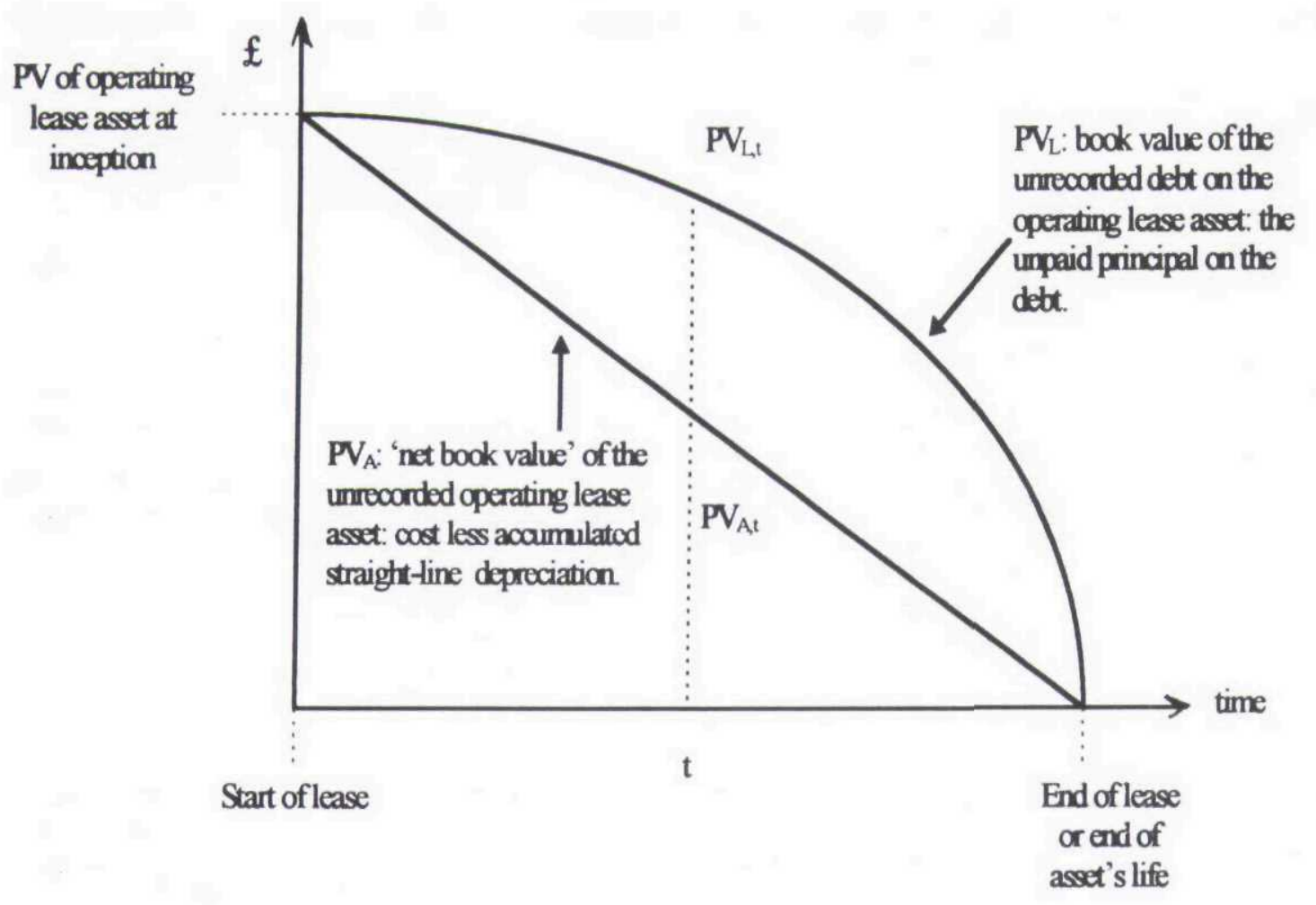

Source: Based on Figure 1 in Imhoff, Lipe and Wright (1991: 57)

and $80 \%$ in $51(49 \%)$ cases. Based on this, their fourth assumption is that an appropriate approximation for the asset proportion is $70 \%$.

The income statement effect of operating lease capitalisation is shown in Figure 3, which compares the annual profit and loss charge under both accounting treatments over the lease/asset life. In the early stages of a lease's life, the profit and loss account charge under capitalisation (i.e., depreciation plus interest) exceeds the charge under noncapitalisation (i.e., lease rental, OLR). The difference gradually declines, then reverses. ILW assume that a stable lease portfolio exists (i.e., on average, $50 \%$ of lease life remains) and that this average remaining age approximates to the point of indifference between the impact of capitalisation and non-capitalisation on the profit and loss account. This justifies ILW's fifth assumption that the effect on the current period's net income is zero; it is also consistent with the $70 \%$ asset/liability relationship.

The difference between asset value and liability reflects the accumulated effect of the profit reductions in the early years of leases and equates to a reduction in equity. However, the reduction in profit also implies a reduced tax charge'. ILW capture the tax consequences of capitalisation in their sixth assumption: that the combined effective tax rate is $40 \%$ which approximates to McDonalds' actual effective tax rate in 1988 of $38.3 \%$. The excess of the unrecorded lease liability over the unrecorded lease asset is taxed at this rate to reflect the effect on (deferred) tax.

\section{Methods}

\subsection{Sample selection}

A large, randomly selected sample of 300 listed industrial and commercial companies was selected for analysis. Financial companies were excluded as our analysis of the Extel Company Analysis database showed this sector to employ minimal leasing. In addition, many financial companies are likely to be substantial lessors; the impact of re-

${ }^{1}$ The tax payment will not be affected as the tax rules currently allow full deductibility of operating lease rentals, but the charge will be adjusted by a transfer from deferred tax in accordance with the accruals/matching principle. 


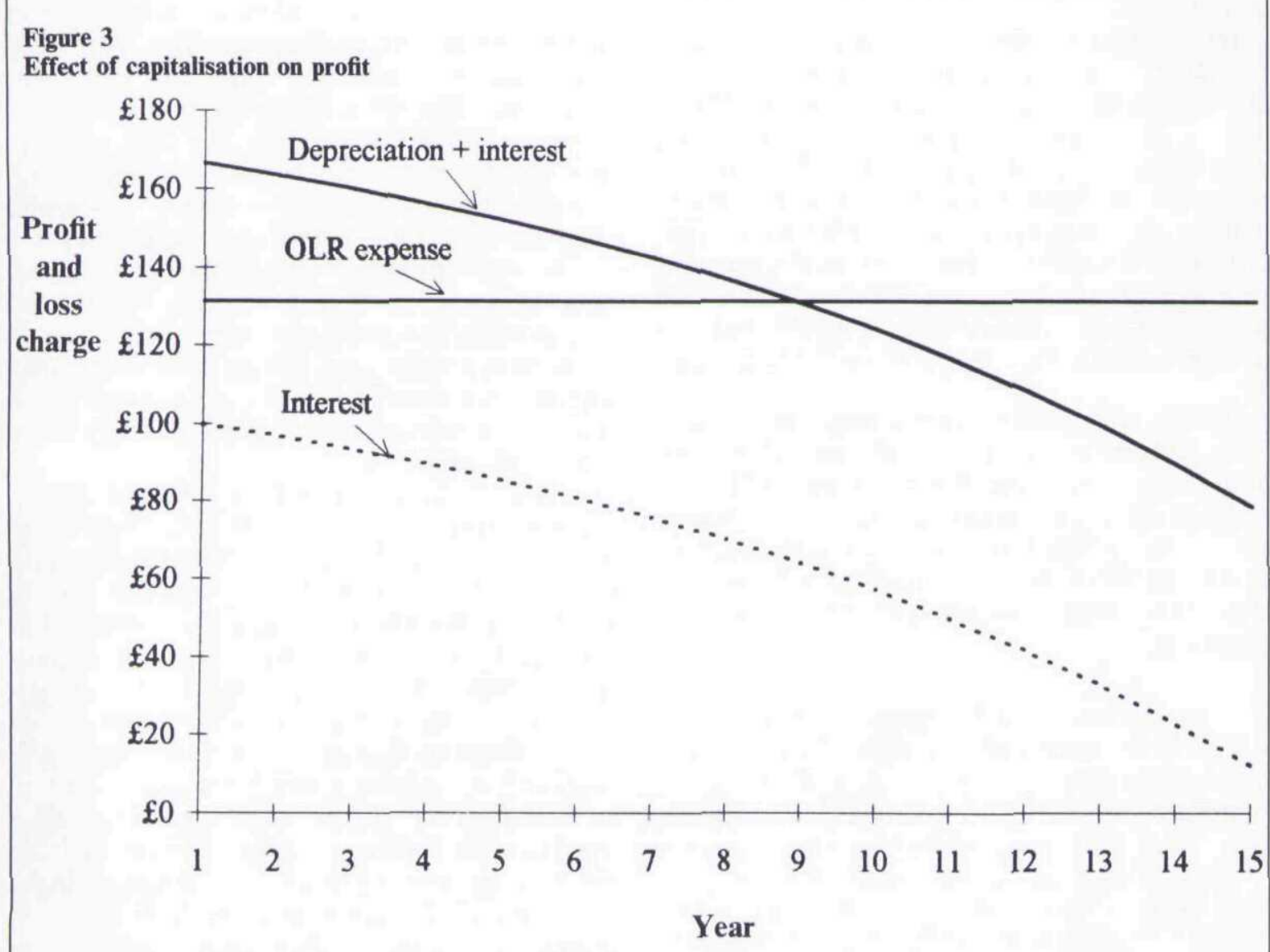

Source: Based on Figure 2 in Imhoff, Lipe and Wright (1991: 59)

Illustration is based on an asset value of $£ 1,000$ leased over 15 years with an implicit interest of $10 \%$ per annum. This gives an annual operating lease rental expense (OLR) of $£ 131.47$. If the asset is capitalised, the straight-line depreciation charge will be $£ 66.67$ per annum. In year 1, the interest element of the OLR will be $£ 100$. Thus, if capitalised, the operating profit (EBIT) will increase by $£ 64.80(+£ 131.47-£ 66.67)$ but profit before tax will fall by $£ 35.20(+£ 131.47-£ 66.67-£ 100)$. If the effective tax rate was $30 \%$, say, then the tax charge will be $£ 10.56$ lower $(30 \%$ of 35.20$)$ and the profit after tax will reduce by $£ 24.64(-£ 35.20+£ 10.56)$.

It is assumed that (i) the primary lease period is less than or equal to the useful life of the asset, and (ii) straight-line depreciation is based on the shorter of the primary lease period and the useful life (consistent with the SSAP 21 required treatment for finance leased assets).

porting changes on lessors is outside the scope of the present study. The UKQI list current in 1995 (the year in which the sampling was undertaken) was used as the initial sampling frame. This Datastream listing of approximately 1,300 companies contains all the UK industrial and commercial companies for which Datastream has accounting information. A particular methodological problem in studies concerning performance is 'survivorship bias', which refers to the use of samples which are biased towards long-surviving companies (see, for example, Brown et al., [1992], for a review of this problem).
To overcome this problem, the 1995 UKQI list was augmented by a group of approximately 250 'dead' companies (failed, taken over, or gone private), identified from a comparison of the Times 1,000 1981/82 top UK companies (no historic UKQI list being available) with the 1995 UKQI list. The year 1981 was selected for comparison purposes because it is the year in which ED 29 was published, and some of our analysis therefore covers the 14 year period 1981 to 1994 . The final sample of 300 companies comprised 53 'dead' companies, 122 'new' companies, and 125 companies which had existed from 1981 to 1994. 


\subsection{Data collection and sample representativeness checks}

Information to enable key pre-operating lease capitalisation ratios and the effective tax rate of each company to be calculated was extracted from Datastream. Eleven profit and loss and balance sheet items and industry group membership were collected (see Table 2, panel A). Leasing data to support the operating lease capitalisation procedure is contained in the notes to the accounts (not available in Datastream); this was extracted manually from company microfiches. The detailed information collected is shown in Table 2, panel B.

At this point, sample representativeness checks were performed, based on total assets (item 392) and share capital and reserves (item 307). This showed that the company size distribution and industry sector distribution of the sample approximated closely to that of the population, indicating that the sample adequately represented the population. $^{2}$

\subsection{Modification of ILW capitalisation procedure}

The ILW procedure was adapted to take into account the different operating lease disclosure requirements in the UK. In addition, to assess the

\footnotetext{
${ }^{2}$ The mean total assets for the sample is $115 \%$ of the population mean total assets, while the mean share capital and reserves for the sample is $127 \%$ of the population share capital and reserves. The size distribution of the sample companies was also positively skewed (coefficient. $=8.3$ ), consistent with observed population skewness.
}

appropriateness of ILW's assumptions for the UK environment, we first undertook a preliminary analysis regarding operating lease lives. This failed to produce reasonable and consistent results, due to the considerable variation in leasing patterns within our sample companies. The pattern of operating lease commitments over the period 1985 through 1994 was analysed for a small sub-sample of companies. This identified some companies with commitments predominantly in the ' $>$ five years' category, some predominantly spread over the two ' $\leq$ five years' categories, and some spread over all three expiry categories. Thus, some companies take on only short- to medium-term leases, some mainly long-term leases, and some the whole range of lease durations.

ILW's assumption of uniform total and remaining lease lives is unable to capture such diversity. In particular, calculation of the impact of capitalisation on the profit and loss account (not investigated by ILW) would be severely distorted. For example, imagine a company which takes on only medium-term leases of, say, five years. In a steadystate, the average remaining life for the company's leases would be approximately three years. ILW suggested a uniform assumption of 15-year remaining lease life. If this were applied to such a company, the depreciation charge in the P\&L account upon capitalisation of the operating leases would be one-fifteenth of the asset value (assuming straight-line method) rather than one-third and would give a large understatement of the effect on operating and pre-tax profit.

Table 2

Data collected for each year from 1981 to 1994 inclusive for 300 sample companies

Panel A: Datastream

Item description

Sales

Total interest charges

Pre-tax profit - adjusted

Total tax charge - adjusted

Total share capital and reserves

Borrowings due within one year

Total loan capital

Total capital employed

Total cash and cash equivalents

Total current liabilities

Total assets

Industry group
Datastream code

104

153

157

172

307

309

321

322

375

389

392

Level 3

\section{Panel B: Company microfiche}

Profit and loss account charge for operating lease rental, split into plant and equipment, land \& buildings, and other, where given.

Note to the accounts giving operating lease commitments due within the next year, split into asset category and lease expiry category. 
We therefore developed ILW's method to incorporate company-specific assumptions in respect of the remaining lease life, the asset proportion, and the effective tax rate. We also distinguish in our analysis between asset categories and lease expiry categories, performing separate calculations of remaining lease life and asset proportion for each. Our capitalisation procedure is now described in detail.

The operating lease information disclosed by UK companies in a note to the financial statements is a schedule of next year's operating lease payments (compared to the minimum total future payments disclosed by US companies). This figure is analysed by asset category (i.e., 'land and buildings' and 'other') and by lease expiry date (i.e., leases expiring within one year, between one and five years, and after five years). Although generally less complete than US disclosures, UK disclosures do have the advantage of giving a more reliable picture of the company's pattern of remaining lease lives. Figure 4 provides an illustration of UK disclosure in respect of the 'land and buildings' category (Panel B) and of US disclosure (Panel A), reported voluntarily in this case by the company.

We first used 13 cases of such combined US and UK disclosure by UK companies to develop base estimates of remaining and total lease lives appropriate to the UK setting. These cases were contained in the accounts of seven companies between 1987 and 1995, and were taken from 20F forms and from voluntary disclosures identified during

\section{Figure 4}

Illustration of calculation of remaining lease life estimate for company disclosing both minimum total future operating lease payments and next year's commitment

Company Name: NFC plc

Asset category: Land and buildings

Year-end: $\quad 30$ September 1995

All monetary values in $\mathrm{fm}$

Panel A

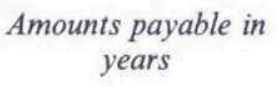

$<1$

$1-5$

$>5$

Total commitment

Panel B
Minimum total future operating lease payment (TCF)

61.2

162.6

290.0

$\overline{513.8}$

Next year's operating lease commitment (CFI) 17.9

24.7

18.6

$\overline{61.2}$

Since the total lease liability beyond year five $\left(\mathrm{TCF}_{>5}=£ 290 \mathrm{~m}\right)$ can only relate to leases expiring beyond year five, and assuming that next year's commitment for leases expiring after five years $\left(\mathrm{CF}_{3}=£ 18.6 \mathrm{~m}\right)$ is constant over the remaining life of the leases, then the $£ 290 \mathrm{~m}$ represents 15.6 years payments after year five, giving a total remaining life of 20.6 years (on average), i.e.,

$$
\mathrm{RL}_{3}=\frac{\mathrm{TCF}_{>5}}{\mathrm{CF} 1_{3}}+5=\frac{290.0}{18.6}+5=20.6 \text { years }
$$

The total liability between years one and five $\left(\mathrm{TCF}_{1<t \leq 5}=£ 162.6 \mathrm{~m}\right)$ relates to leases expiring beyond year five, as well as those expiring within the one to five year period. Assuming four years of the constant annual payment of $£ 18.6 \mathrm{~m}$ relating to the former leaves $£ 88.2 \mathrm{~m}$ relating to the latter. This equates to 3.6 years of constant $£ 24.7 \mathrm{~m}\left(\mathrm{CF}_{2}\right)$ after the first year giving an average remaining life of 4.6 years for this category, i.e.,

$$
\mathrm{RL}_{2}=\frac{\mathrm{TCF}_{1<\mathrm{t} \leq 5}-\left(4 \times \mathrm{CF}_{3}\right)}{\mathrm{CF} 1_{2}}+1=\frac{162.6-(4 \times 18.6)}{24.7}+1=4.6 \text { years }
$$

The remaining life for the ' $<1$ year' expiry category is assumed to be one year exactly, consistent with the general assumption of year end cash flows, i.e.:

$$
\mathrm{RL}_{1}=1
$$


data collection. ${ }^{3}$ Figure 4 also provides an illustration of the base estimate calculations for one of the thirteen cases.

For each asset category, the total next year's operating lease payments can be expressed as:

$$
\sum_{\mathrm{e}=1}^{3} \mathrm{CF} 1_{\mathrm{e}}
$$

where $\mathrm{e}=$ lease expiry category $(\mathrm{e}=1$ (within one year), 2 (between one and five years), and 3 (after five years)). This describes the total of $£ 61.2 \mathrm{~m}$ in panel B of Figure 4.

The additional US-style disclosures permitted the remaining lease life of each lease expiry category to be estimated as follows:

$$
\mathrm{RL}_{3}=\frac{\mathrm{TCF}_{>5}}{\mathrm{CF}_{3}}+5
$$

where $\mathrm{RL}_{e}=$ the remaining lease life of assets in lease expiry category e,

$\mathrm{TCF}_{\mathrm{t}}=$ minimum total future operating lease cash flows payable in period $\mathrm{t}$, and

$\mathrm{CF}_{\mathrm{e}}$ = next year's operating lease cash flows for assets in lease expiry category e.

The first term in equation 3 represents an estimate of the number of years' payments included in TCF, assuming that the next year's payment (CF1) is, on average, constant throughout the life of the lease. In the example in Figure $4, \mathrm{RL}_{3}$ is calculated to be 20.6 years. Similarly,

$$
\mathrm{RL}_{2}=\frac{\mathrm{TCF}_{1<\mathrm{t} \leq 5}-\left(4 \times \mathrm{CF}_{3}\right)}{\mathrm{CF}_{2}}+1
$$

In the example in Figure 4, $\mathrm{RL}_{2}$ is calculated to be 4.6 years. Note that $R_{1}$ is taken to be one year, assuming year-end cash flows.

Remaining life estimates for each of the thirteen identified cases were averaged to give base estimates $\left(\mathrm{RL}_{\mathrm{base}}\right)$ for application to the whole sample. These cases were also used to subjectively estimate suitable corresponding base total lease lives $\left(\mathrm{TL}_{\text {base }}\right)$, based on the remaining lease life and the observation that the lease portfolio of our companies was generally quite young. These estimated lease lives are shown in Table $3.4,5$ As discussed

\footnotetext{
${ }^{3}$ The 'Form 20-F' report to the SEC is required by companies that sponsor an ADR (American Depository Receipt) which is traded on one of the national stock exchanges such as the NYSE, the AMEX or NASDAQ. It contains additional disclosures not required by UK regulations. Other companies voluntarily disclosed minimum total future operating lease payments.

${ }^{4}$ Further support for the use of a 25-year total lease life for land and buildings was provided by the disclosure of lease contract details relating to 29 separate properties valued over $£ 1 \mathrm{~m}$ in the 1996 Report of Legal \& General Investment Management Property Fund Portfolio. The median total lease life was 25 years, accounting for $62 \%$ of the individual leases.

${ }^{5}$ These base estimates for the ' $<1$ year' and '1 to 5 years' categories (assumed to be 1 and 5 years, respectively) ignore
}

above, for the purpose of assessing the 'asset proportion', these estimates were rejected as valid common assumptions for all companies, and were refined by weighting each base lease life by the individual company's cumulative historic (from 1981 to 1994 , inclusive) volume of leases in the lease expiry category. This refinement seeks to estimate an overall weighted average life which reflects each particular company's lease profile; while not rigorously determined, this adjusts in an appropriate direction. Use of the cumulative historic volume of leases in each lease expiry category might be expected to give a more reliable indication of the average proportion of lease life expired than the use of data from a single year. ${ }^{6}$

The weight for lease expiry category e $\left(w_{e}\right)$ is given by:

$$
\mathrm{w}_{\mathrm{e}}=\sum_{\mathrm{e}=1}^{3}\left(\frac{\sum_{\mathrm{t}=1981}^{1994} \mathrm{CF} 1_{\mathrm{t}, \mathrm{e}}}{\sum_{\mathrm{e}=1}^{3} \sum_{\mathrm{t}=1981}^{1994} \mathrm{CF} 1_{\mathrm{t}, \mathrm{e}}}\right) R \mathrm{~L}_{\mathrm{base}, \mathrm{e}}
$$

and the weighted average remaining life for company $\mathrm{i}\left(\mathrm{RL} \mathrm{L}_{\mathrm{i}}\right)$ is:

$$
\mathrm{RL}_{\mathrm{i}}=\sum_{\mathrm{e}=1}^{3} \mathrm{w}_{\mathrm{e}} \mathrm{RL}_{\text {base }, \mathrm{e}}
$$

Similarly, the weighted average total life for company $\mathrm{i}\left(\mathrm{TL}_{\mathrm{i}}\right)$ is:

$$
\mathrm{TL}_{\mathrm{i}}=\sum_{\mathrm{e}=1}^{3} \mathrm{w}_{\mathrm{e}} \mathrm{TL}_{\text {base,e }}
$$

the liability which relates to longer expiry categories. To illustrate, consider the next year's commitment for leases expiring in less than 1 year. This could relate entirely to the final year's payment due on a 25 year lease, or entirely to 1 year leases, with the most likely scenario somewhere between these extremes. The weighting of base estimates reflects this variation. For example, if the first extreme scenario were true, then the '> 5 years' category would almost certainly represent the major category historically, and so the weighted average remaining life would be weighted appropriately towards 25 years.

${ }^{6}$ An alternative approach, suggested by one of the referees, is to use the particular year's reported operating lease commitment to estimate the weighted average total life of leased assets. This has the advantage of reflecting any changes in lease profile and is also consistent with the calculation of $\mathrm{PV}_{\mathrm{L}}$. However, it does not allow the historical pattern of one-year commitments to be reflected in the ratio of asset to liability. This alternative approach was tested on the full sample of companies for 1994. For individual companies there were changes to the asset proportion and to depreciation, and therefore also to the effect on annual profit and loss and related ratios. The overall impact on mean ratios (as reported in Table 7) was very small. One ratio (return on equity) showed increased variability and, as a result, the slightly higher post-capitalisation ratio of $8.37 \%$ was statistically insignificant (it is reported as significant at the $5 \%$ level in Table 7). Similarly, the maximum impact on rank correlations (as reported in Table 9) of 0.001 was minimal. In view of these findings, only the results based on the historical weighted average total life are reported. 
Table 3

Base estimates of remaining and total lease lives calculated from Form $20 \mathrm{~F}$ and voluntary disclosures

\begin{tabular}{|c|c|c|c|c|}
\hline \multirow[b]{2}{*}{$\begin{array}{l}\text { Lease expiry } \\
\text { category (years) }\end{array}$} & \multicolumn{2}{|c|}{$\begin{array}{l}\text { Remaining lease } \\
\quad \text { life }\left(R L_{\text {base }}\right)\end{array}$} & \multicolumn{2}{|c|}{ Total lease life $\left(T L_{\text {base }}\right)$} \\
\hline & $\begin{array}{l}\text { Land \& } \\
\text { buildings }\end{array}$ & Other & $\begin{array}{l}\text { Land \& } \\
\text { buildings }\end{array}$ & Other \\
\hline Less than one & 1 & 1 & 1 & 1 \\
\hline One to five & 3 & 3 & 5 & 5 \\
\hline More than five & 16 & 7 & 25 & 10 \\
\hline
\end{tabular}

In contrast to ILW's procedure, which assumes that the weighted average remaining and total lease lives are constant across companies, our procedure establishes company-specific estimates which are assumed merely to remain stable for a given company over time. ${ }^{7}$

We selected a short-term borrowing rate, the three-month London deposit rate, as a suitable discount rate to use to discount the estimated future lease payments. This rate is similar to the Finance House Base Rate, used by members of the Finance and Leasing Association. The mean monthly rate (extracted from Datastream) for 1981 to 1994 was $10.8 \%$ and for the most recent business cycle (1988 to 1994$)$ was $10.3 \%$. We selected $10.3 \%$ as the most suitable discount rate, since the study covers 1990 to 1994 , rounded to $10 \%$.

Although the capitalisation of operating leases would not affect the amount of tax payable under current tax law, the amounts of tax charged to the current period and deferred to future periods are affected. An effective tax rate has to be calculated to incorporate this effect. Since this rate can vary considerably over time, the average effective tax rate for each company was calculated over the period 1981 to $1994 .^{8}$

These company-specific remaining and total lease life estimates, and effective tax rate estimates, were then used to perform the constructive capitalisation of operating leases using the procedures of ILW (1991). The present value of the unrecorded liability $\left(\mathrm{PV}_{\mathrm{L}}\right)$ for company $\mathrm{i}$ is calculated as:

\footnotetext{
${ }^{7}$ Twenty-four companies did not disclose the split between asset categories, which affects the calculation of remaining and total lease lives for the 'more than five years' lease expiry category. To provide an estimate of the likely split for these companies, we calculated the mean split within each of the five industry groups using data from the remainder of the sample, cumulated over the period 1981 to 1994 . The relevant mean industry split was then imputed in the place of the missing values.

${ }^{8}$ The data was winsorised; a technique to reduce the impact of serious outliers and non-normality, i.e., extreme observations (less than $0 \%$ or more than $50 \%$ ) were reset to $0 \%$ and $50 \%$, respectively (Foster, 1986: 103).
}

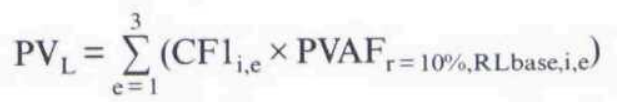

The corresponding present value of the unrecorded asset for company $\mathrm{i}$ is:

$$
\mathrm{PV}_{\mathrm{A}}=\mathrm{PV}_{\mathrm{L}} \times \frac{\mathrm{RL}_{\mathrm{i}} \times \mathrm{PVAF}_{\mathrm{r}=10 \%, \mathrm{TLi}}}{\mathrm{TL}_{\mathrm{i}} \times \mathrm{PVAF}_{\mathrm{r}=10 \%, \mathrm{RLi}}}
$$

where PVAF $_{r, n}$ represents the present value of an annuity of $£ 1$ for $n$ periods at interest rate $r \%$. $P V_{L}$ and $\mathrm{PV}_{\mathrm{A}}$ are calculated separately for both asset categories (i.e. for 'land and buildings' and 'other') and summed to give total unrecorded liabilities and assets. An illustration of this calculation for one company is given in Table $4 .{ }^{9}$

\subsection{Impact of capitalisation on key accounting ratios}

To facilitate comparison with previous studies, nine performance and gearing ratios were investigated, comprising the six ratios used by Ashton (1985), the two used by ILW (1991), and an additional gearing ratio (a variant used extensively in corporate annual reports). ${ }^{10}$ Due to their assumption that operating lease capitalisation is incomeneutral, ILW originally examined only return on assets and gearing ratios. Their subsequent paper (ILW, 1997) relaxes this assumption. The definitions of the nine ratios examined, and the corre-

\footnotetext{
${ }^{9}$ Alternative approaches, involving three different assumptions, were also tried independently. First, operating lease rental was taken as the reported operating lease rental expense, rather than next year's operating lease commitment. Second, the operating lease liability for each asset category was estimated based on the overall average remaining life, rather than considering expiry categories individually. This allows the historic lease obligation profile to be reflected in both asset and liability estimates. Third, the $\mathrm{PV}_{\mathrm{A}} / \mathrm{PV}_{\mathrm{L}}$ proportion was estimated for each expiry category, rather than using the overall average remaining and total lease lives. The results reported here are robust with respect to these alternatives.

${ }^{10}$ Many company managers seem to favour the net debt to equity ratio measure of gearing, claiming that the deduction of cash (and often also short-term investments) gives a fairer picture of the debt exposure facing the company. The definition adopted here included short-term borrowings within debt.
} 


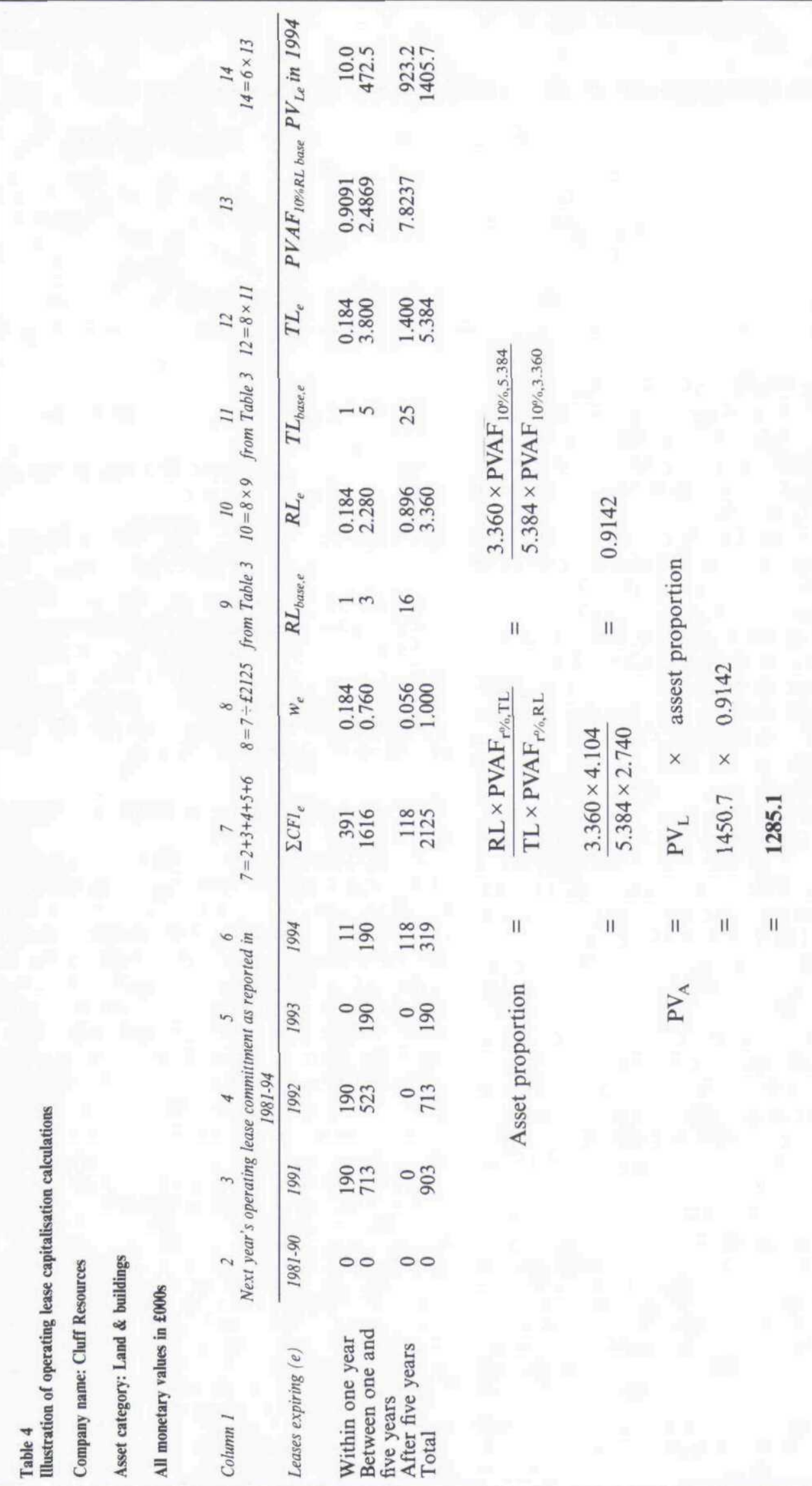


sponding Datastream item codes, are given in Table 5, panel A, columns 2 and 3 . The impact of operating lease capitalisation on the constituent accounting numbers is shown in Table 5, panel B.

To calculate post-capitalisation earnings before interest and tax (EBIT), the annual operating lease rental is added back and annual straight line depreciation of the capitalised asset is deducted from pre-capitalisation EBIT. To calculate post-capitalisation profit after interest and tax (PAIT), precapitalisation PAIT is adjusted by the net-of-tax effect of adding back annual operating lease rental and deducting both annual straight line depreciation of the capitalised asset and annual lease interest expense. The expected direction of change in each ratio following operating lease capitalisation is given in the final column of Table 5, panel A.

\section{Results}

\subsection{Impact in 1994}

This analysis is based on 232 of the 247 'new' and 'continuing' companies. Five companies were eliminated from the sample at the data collection stage, because their accounts had not been updated on Datastream. A further 10 companies were excluded due to outlying observations (negative equity or capital employed before or after capitalisation) which would have distorted the sample means severely. Table 6 provides a summary of the estimated mean capitalised value of operating lease assets and liabilities for 1994. Overall, the mean total liability in respect of operating leases was $£ 51 \mathrm{~m}$, of which $£ 8 \mathrm{~m}$ would be classified on the balance sheet as short-term (i.e., due within one year) and $£ 43 \mathrm{~m}$ as long-term (i.e., due after more than one year). ${ }^{11}$

On average, the latter represented $39 \%$ of long-term debt before capitalisation. Wide variation was observed across the five sectors, ranging from a mean long-term liability of just $£ 6 \mathrm{~m}(3 \%$ of long-term debt) for mineral extraction, to $£ 88 \mathrm{~m}$ (69\% of long-term debt) for the services sector. Capitalised operating lease asset values ranged from a mean of $£ 5 \mathrm{~m}$ for mineral extraction to $£ 80 \mathrm{~m}$ for services, with an overall mean of $£ 40 \mathrm{~m}$, representing $0.8 \%, 13 \%$, and $6 \%$ of pre-capitalis-

\footnotetext{
"I Of the sample, $16 \%$ had no operating leases; the equivalent figures based on only those companies with operating leases rise to, approximately, $£ 61 \mathrm{~m}$ (total), $£ 10 \mathrm{~m}$ (short-term), and $£ 51 \mathrm{~m}$ (long-term).
}

ation total assets, respectively. ${ }^{12}$ Thus, operating leases represent a major source of long-term debt-type financing in the UK. Under current accounting regulations, approximately $39 \%$ of longterm liabilities do not appear on the balance sheet, with total assets being understated by approximately $6 \%$.

The magnitude and statistical significance of the changes in the nine selected ratios following operating lease capitalisation is shown in Table 7. Statistical significance was examined using both the paired t-test and the Wilcoxon test, which test for differences between the pre- and post-capitalisation ratios, based on absolute values and rank difference values, respectively. Only t-test results are reported here; the corresponding non-parametric test (the Wilcoxon signed ranks test of change in medians) consistently produced results of greater significance. ${ }^{13}$ Two-tailed tests were used throughout, despite the existence of uni-directional expectations (which were confirmed) for six of the ratios; thus the reported significance levels for these ratios are conservative. For the sample as a whole, a significant impact at the $1 \%$ level was observed for six of the ratios (profit margin, return on assets, asset turnover, and the three gearing measures), with a further one ratio significant at the $5 \%$ level (return on equity). Return on capital employed and interest cover were not significantly affected. Of the three gearing measures, the percentage change in the net debt to equity ratio $(260 \%)$ is particularly striking. Since this gearing measure produces a lower figure pre-capitalisation than the ILW total debt to equity ratio, the capitalised lease liability has a greater proportionate impact.

The pattern of results across industry groups is also reported in Table 7 , although these results must be compared with caution since the number of companies in each group varies considerably, with the mineral extraction and utilities groups being very small in size. The effect of operating lease capitalisation on profit margin, asset turnover, and the three gearing measures is significant at the $1 \%$ level for three industry groups-consumer goods, general industrial, and services. The only significant results for these five ratios in the remaining two industry groups are profit margin (significant

\footnotetext{
12 The median capitalised value of operating lease liabilities was only $£ 4.1 \mathrm{~m}$, compared to the mean of $£ 51 \mathrm{~m}$. However, the relative magnitude of this figure must be assessed in the context of the positively skewed nature of the distributions of company size and capitalised operating lease assets and liabilities. The long-term element of the median total liability was $£ 3.2 \mathrm{~m}$, which represents $140 \%$ of the median long-term debt before capitalisation. The median value of capitalised operating lease assets was $£ 3.3 \mathrm{~m}$ compared to the mean of $£ 40 \mathrm{~m}$. This represents $5.4 \%$ of median total assets before capitalisation.

${ }^{13}$ The use of a non-parametric test takes into account the non-normal distribution of many ratios (Barnes, 1987).
} 


\section{Table 5 \\ Definition of key ratios and the impact of operating lease capitalisation on constituent accounting numbers}

Panel A: Definitions of key ratios

\begin{tabular}{|c|c|c|c|}
\hline Ratio & Definition & $\begin{array}{l}\text { Datastream } \\
\text { definition }\end{array}$ & $\begin{array}{l}\text { impact of } \\
\text { capitalisati }\end{array}$ \\
\hline Profit margin & $\frac{\text { Earnings before interest \& tax (EBIT) }}{\text { Sales }}$ & $\frac{157+153}{104}$ & + \\
\hline Return on equity & $\frac{\text { Profit after interest \& tax (PAIT) }}{\text { Equity }\left(\mathrm{E}_{\text {Ashton }}\right)}$ & $\frac{157-172}{307}$ & tor- \\
\hline Return on assets & $\frac{\text { Profit after interest \& tax }}{\text { Total assets (TA) }}$ & $\frac{157-172}{392}$ & - \\
\hline $\begin{array}{l}\text { Return on capital } \\
\text { employed }\end{array}$ & $\frac{\text { Earnings before interest \& tax }}{\text { Capital employed }(\mathrm{CE})}$ & $\frac{157+153}{322}$ & tor- \\
\hline Asset turnover & $\frac{\text { Sales }}{\text { Capital employed }}$ & $\frac{104}{322}$ & - \\
\hline Interest cover & $\frac{\text { Earnings before interest \& tax }}{\text { Interest (I) }}$ & $\frac{157+153}{153}$ & tor- \\
\hline Gearing $_{\text {Ashton }}$ & $\frac{\text { Long-term debt (LTD) }}{\text { Capital employed }}$ & $\frac{321}{322}$ & + \\
\hline Gearing $_{\mathrm{ILw}}$ & $\frac{\text { Total debt (D) }}{\text { Equity }\left(\mathrm{E}_{\mathrm{ILw}}\right)}$ & $\frac{321+389}{307}$ & + \\
\hline Gearing & $\frac{\text { Total borrowing less cash \& cash equivalents (TB) }}{\text { Equity }\left(\mathrm{E}_{\mathrm{ILw}}\right)}$ & $\frac{321+309-375}{307}$ & + \\
\hline
\end{tabular}

Panel B: Impact of operating lease capitalisation on constituent accounting numbers

$$
\begin{aligned}
& \text { EBIT }_{\text {post }}=\text { EBIT }_{\text {pre }}+\text { OLR }- \text { depn } \\
& \text { PAIT }_{\text {post }}^{\text {post }}=\text { PAIT }_{\text {pre }}+(1-\mathrm{T})(\text { OLR }- \text { depn }- \text { int }) \\
& \mathrm{E}_{\text {Ashton, post }} \quad=\mathrm{E}_{\text {Aston, pre }}-\left(\mathrm{PV}_{\mathrm{L}}-\mathrm{PV}_{\mathrm{A}}\right) \\
& \mathrm{TA}_{\text {post }} \quad=\mathrm{TA}_{\text {pre }}+\mathrm{PV}_{\mathrm{A}} \\
& \mathrm{CE}_{\text {post }}^{\text {ost }} \quad=\mathrm{CE}_{\text {pre }}+\mathrm{PV}_{\mathrm{A}}^{\mathrm{A}}-[\mathrm{OLR} /(1+\mathrm{i})] \\
& \mathrm{I}_{\text {post }} \quad=\mathrm{I}_{\text {pre }}+\text { int } \\
& \text { int } \quad=\left[\mathrm{i} \times\left(\mathrm{PV}_{\mathrm{L}}+\mathrm{OLR}\right)\right] /(1+\mathrm{i}) \\
& \mathrm{D}_{\text {ILW, post }} \quad=\mathrm{D}_{\mathrm{ILW} \text {, pre }}+\mathrm{PV}_{\mathrm{L}}-\mathrm{T}\left(\mathrm{PV}_{\mathrm{L}}-\mathrm{PV}_{\mathrm{A}}\right) \\
& \mathrm{E}_{\mathrm{ILW} \text {, post }} \quad=\mathrm{E}_{\mathrm{ILW} \text {, pre }}-(1-\mathrm{T})\left(\mathrm{PV}_{\mathrm{L}}-\mathrm{PV}_{\mathrm{A}}\right) \\
& \mathrm{LTD}_{\text {Ashton, post }}=\mathrm{LTD}_{\text {Asthon, pre }}+\mathrm{PV}_{\mathrm{L}}-[\mathrm{OLR} /(1+\mathrm{i})] \\
& \mathrm{TB}_{\text {post }} \quad=\mathrm{TB}_{\text {pre }}+\mathrm{PV}_{\mathrm{L}} \\
& \text { where } \\
& \text { OLR = annual operating lease rental (for consistency with asset and liability estimates, this was } \\
& \text { taken as next year's operating lease commitment, as specified in the notes to the } \\
& \begin{aligned}
\text { depn } & \text { accounts, rather than the current year reported operat; }
\end{aligned} \\
& \mathrm{T} \quad \text { = effective tax rate; } \\
& \text { int } \quad=\text { annual lease interest expense; } \\
& \mathrm{i} \quad=\text { rate of interest implicit in lease; and } \\
& \text { the subscripts 'pre' and 'post' signify values before and after operating lease capitalisation, respectively. } \\
& \mathrm{T}\left(\mathrm{PV}_{\mathrm{L}}-\mathrm{PV}_{\mathrm{A}}\right) \quad \text { = reduction in deferred tax due to operating lease capitalisation } \\
& \mathrm{OLR} /(1+\mathrm{i}) \quad \text { = short-term portion of lease liability }
\end{aligned}
$$




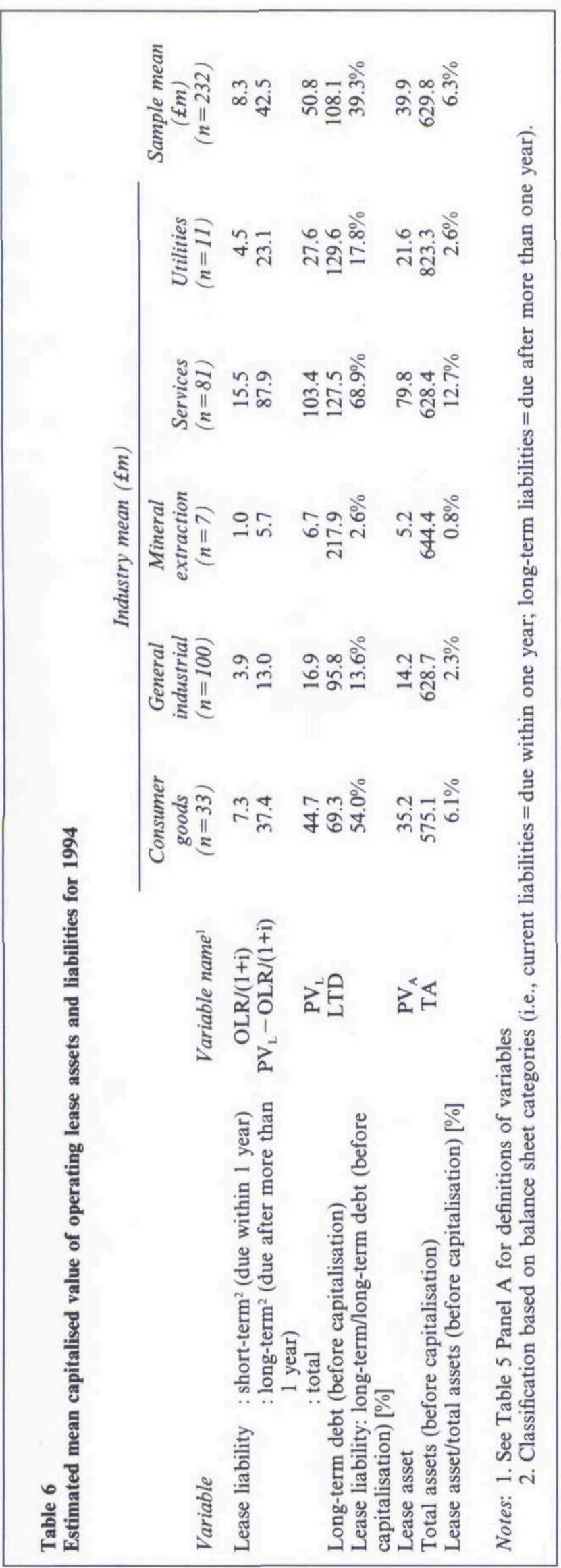




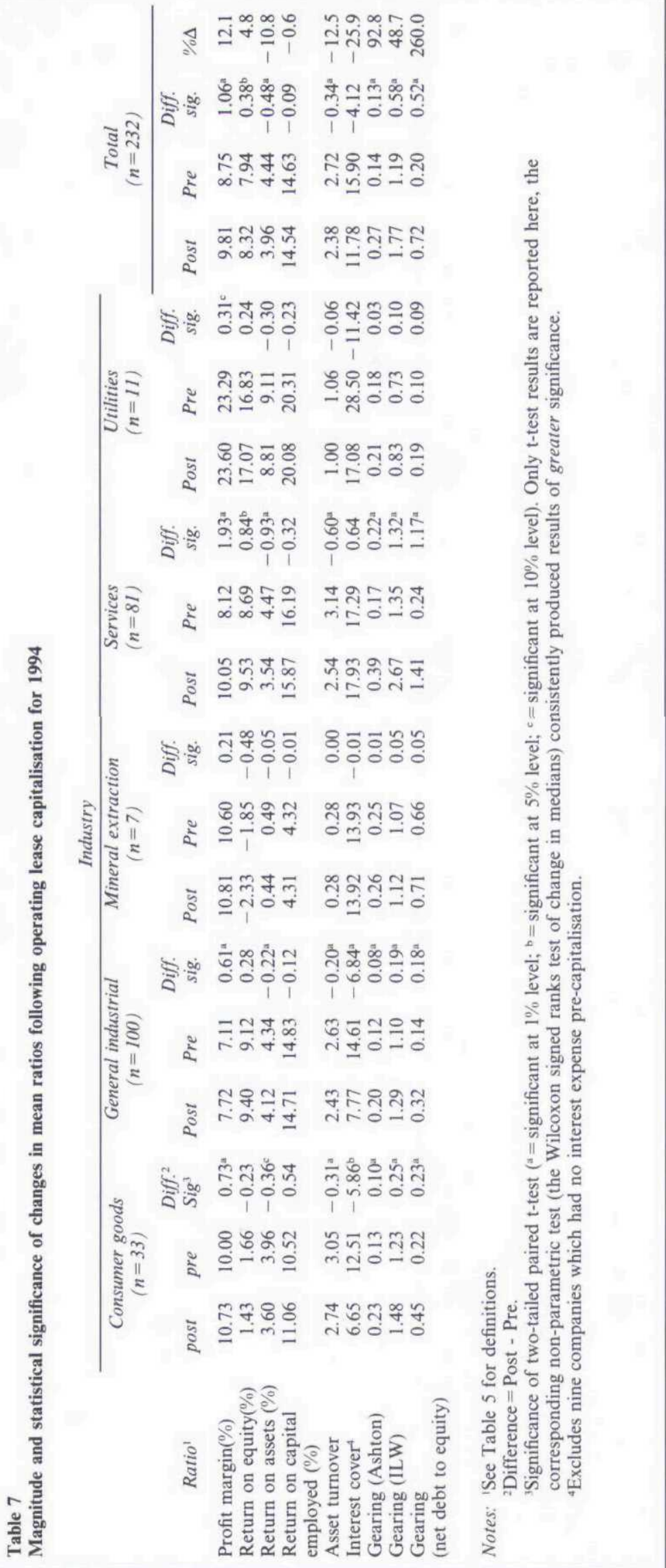


Table 8

Comparison with results of previous studies

Study

Nature of sample

Country

Type of lease capitalised

Ratio

Profit margin

Return on equity

Return on assets

Return on capital

employed

Asset turnover

Interest cover

Gearing Ashton

Gearing

Gearing net debt to equity

Ashton (1985)
$\mathrm{n}=23$; non-random;
1983/84 accounts
UK
Finance

Operating
Present study ${ }^{1}$

$\mathrm{n}=232$; random;

1994 accounts

UK

Operating

Percentage change in ratio following capitalisation and statistical significance ${ }^{2}$

Notes: 1. From Table 7, final column.

2. $\mathrm{NA}=$ ratio not included in study; $\mathrm{NS}=$ not significant; $\mathrm{S}=$ significant; significance of two-tailed paired t-test $(* * *=$ significant at $1 \%$ level; $* *=$ significant at $5 \%$ level; $*=$ significant at $10 \%$ level).

3. Ashton (1985: 236) reports a 'decline' in the gearing ratio of (20.11); in fact the direction of change must be positive.

4. Derived from figures reported in ILW (1991: 61); no statistical tests of significance were performed.

at $10 \%$ for utilities) and Ashton's gearing measure (significant at $10 \%$ for mineral extraction). Return on assets is significant at the $1 \%$ level for general industrial and services and at the $10 \%$ level for consumer goods. Return on equity is significant for only the services sector (at the $5 \%$ level), a result which drives the $5 \%$ significance for the sample as a whole. Interest cover, while insignificant across the whole sample, is significant for the consumer goods and general industrial sectors (at the $5 \%$ and $10 \%$ levels, respectively). Finally, return on capital employed is not significant for any sector (or for the whole sample).

It is noticeable that, based on constructive results, operating lease capitalisation impacts on the services sector most acutely. The effect on all three gearing measures was markedly in excess of that in any other sector, as was the effect on profit margin, return on assets, and asset turnover. This can be explained by the greater reliance on operating leases by this sector. In 1994, the total next year's operating lease commitments of the sample companies alive in that year was $£ 2,208 \mathrm{~m}$. Service sector companies, which account for $37 \%$ of this set by number, account for $69 \%$ of the total commitment. This equates to a mean value of $£ 16.9 \mathrm{~m}$ per services company, the corresponding means for the other four sectors being, in descending order,
$£ 15.4 \mathrm{~m}$ (utilities), $£ 5.8 \mathrm{~m}$ (consumer goods), $£ 3.1 \mathrm{~m}$ (general industrial) and $£ 1.1 \mathrm{~m}$ (mineral extraction).

Our findings with respect to the total sample contrast sharply with those of Ashton (1985), who found only the gearing ratio (out of the six ratios which he examined) to be affected significantly. (Unfortunately, Ashton does not state whether one- or two-tailed tests were used or the cut-off level of significance adopted.) It is likely that the low percentage change in ratios found by Ashton (and their lack of significance) is attributable partly to his exclusive focus on finance leases and his small sample size. Further, his sample consisted entirely of companies which adopted the lease accounting standard at the exposure draft (ED29) stage. It is likely that the expected impact of the change in regulation on early adopters was small. Our findings are, however, less strong than those of ILW, who do consider operating leases. ILW's results imply a $22 \%$ decline in return on assets for their sample of 14 companies and a $119 \%$ increase in gearing (statistical significance is not considered). The comparable figures in the present study are $-11 \%$ and $+49 \%$, respectively. This is surprising, given the greater stringency of US lease accounting regulation which leads us to expect, ceteris paribus, operating lease capitalisation to 
Table 9

Rank correlation of pre- and post-operating lease capitalisation ratios for 1994

\begin{tabular}{|c|c|c|c|c|c|c|}
\hline \multirow[b]{2}{*}{ Ratio $^{1}$} & \multicolumn{5}{|c|}{ Industry } & \multirow[b]{2}{*}{$\begin{array}{c}\text { Total } \\
(n=232)\end{array}$} \\
\hline & $\begin{array}{l}\text { Consumer } \\
\text { goods } \\
(n=33)\end{array}$ & $\begin{array}{c}\text { General } \\
\text { industrial } \\
(n=100)\end{array}$ & $\begin{array}{c}\text { Mineral } \\
\text { extraction } \\
(n=7)\end{array}$ & $\begin{array}{l}\text { Services } \\
(n=81)\end{array}$ & $\begin{array}{l}\text { Utilities } \\
(n=11)\end{array}$ & \\
\hline Profit margin & 0.988 & 0.985 & 1.000 & 0.903 & 1.000 & 0.953 \\
\hline Return on equity & 0.997 & 0.998 & 0.964 & 0.988 & 1.000 & 0.996 \\
\hline Return on assets & 0.956 & 0.992 & 1.000 & 0.933 & 0.936 & 0.966 \\
\hline Return on capital employed & 0.999 & 0.997 & 1.000 & 0.982 & 1.000 & 0.992 \\
\hline Asset turnover & 0.987 & 0.978 & 1.000 & 0.890 & 1.000 & 0.934 \\
\hline Interest cover ${ }^{2}$ & 0.809 & 0.945 & 1.000 & 0.732 & 0.782 & 0.826 \\
\hline Gearing $_{\text {Ashton }}$ & 0.701 & 0.771 & 1.000 & 0.418 & 0.636 & 0.638 \\
\hline Gearing $_{\text {ILW }}$ & 0.950 & 0.925 & 0.964 & 0.710 & 0.963 & 0.857 \\
\hline Gearing $_{\text {net debt to equity }}$ & 0.837 & 0.927 & 1.000 & 0.534 & 0.864 & 0.738 \\
\hline $\begin{array}{ll}\text { Notes: } & \text { 1. See Table } 5 \text { for } d \\
& \text { 2. Excludes nine con }\end{array}$ & th no inte & t expens & re-capitali & & & \\
\hline
\end{tabular}

Table 10

Magnitude and statistical significance of changes in mean ratios following operating lease capitalisation for 1990 to 1994

Mean difference between pre- and post-capitalisation ratios (significance $)^{2}$

\section{Ratio $^{1}$}

Profit margin

Return on equity

Return on assets

Return on capital employed

Asset turnover

Interest cover

Gearing Ashton

Gearing

Gearing net debt to equity

\begin{tabular}{rrrrc}
\hline 1990 & 1991 & 1992 & 1993 & $\begin{array}{c}1994 \\
\text { (from Table 7) }\end{array}$ \\
$0.93^{\mathrm{a}}$ & $1.10^{\mathrm{a}}$ & $1.23^{\mathrm{a}}$ & $1.24^{\mathrm{a}}$ & $1.06^{\mathrm{a}}$ \\
-2.08 & -11.97 & $-1.22^{\mathrm{c}}$ & -4.46 & $0.38^{\mathrm{b}}$ \\
$-0.51^{\mathrm{a}}$ & -0.26 & $-0.38^{\mathrm{a}}$ & $-0.45^{\mathrm{a}}$ & $-0.48^{\mathrm{a}}$ \\
$-0.76^{\mathrm{b}}$ & 0.69 & 0.40 & 0.23 & -0.09 \\
& & & & \\
$-0.35^{\mathrm{a}}$ & $-0.37^{\mathrm{a}}$ & $-0.39^{\mathrm{a}}$ & $-0.34^{\mathrm{a}}$ & $-0.34^{\mathrm{a}}$ \\
$-17.53^{\mathrm{b}}$ & $-19.88^{\mathrm{b}}$ & $-23.10^{\mathrm{b}}$ & $-18.96^{\mathrm{a}}$ & -4.12 \\
$0.12^{\mathrm{a}}$ & $0.13^{\mathrm{a}}$ & $0.14^{\mathrm{a}}$ & $0.13^{\mathrm{a}}$ & $0.13^{\mathrm{a}}$ \\
$1.06^{\mathrm{c}}$ & $1.18^{\mathrm{a}}$ & $0.88^{\mathrm{a}}$ & $0.70^{\mathrm{a}}$ & $0.58^{\mathrm{a}}$ \\
$0.94^{\mathrm{c}}$ & $0.90^{\mathrm{a}}$ & $0.79^{\mathrm{a}}$ & $0.61^{\mathrm{a}}$ & $0.52^{\mathrm{a}}$
\end{tabular}

Range over period ${ }^{3}$

$$
\begin{gathered}
0.93_{90} \text { to } 1.24_{93} \\
-11.97_{91} \text { to } 0.38_{94} \\
-0.51_{90} \text { to }-0.26_{91} \\
-0.76_{90} \text { to } 0.69_{91} \\
-0.39_{92} \text { to }-0.34_{93.94} \\
-23.10_{92} \text { to }-4.12_{94} \\
0.12_{90} \text { to } 0.14_{92} \\
0.59_{94} \text { to } 1.18_{91} \\
0.52_{94} \text { to } 0.94_{90}
\end{gathered}
$$

Notes: 1 . See Table 5 for definitions.

2. Significance of two-tailed paired t-test $\left({ }^{a}=\right.$ significant at $1 \%$ level; ${ }^{b}=$ significant at $5 \%$ level;

${ }^{c}=$ significant at $10 \%$ level).

3. Subscripts indicate year(s) in which observation occurred.

have a greater impact upon accounting ratios in the UK.

However, ILW's sampling procedures differed from those adopted here in two key respects. ILW's sample comprises an equal number of 'high' lessees and 'low' lessees. Six of the matched pairs were retailers while the seventh was from the transport sector. Thus, all selected companies fall within the services sector (as defined in the present study). Moreover, their sample includes only com- panies which had operating leases $(16 \%$ of the sample in the present study had no operating leases). Each of these differences can be expected to result in larger changes than under random sampling. Table 8 provides a summary of the points of comparison between the Ashton (1985), ILW (1991), and the present study.

Arguably, in some decision contexts, the impact of operating leases capitalisation on the absolute magnitude of ratios is of limited relevance; what 


\section{Table 11}

Rank correlation of pre- and post-operating lease capitalisation ratios for 1990 to 1994

$\begin{array}{lcccccc}\text { Ratio' } & 1990 & 1991 & 1992 & 1993 & \begin{array}{c}1994 \\ \text { (from Table 9) }\end{array} & \begin{array}{c}\text { Range over period } \\ \text { Profit margin }\end{array} \\ \text { Return on equity } & 0.974 & 0.966 & 0.963 & 0.954 & 0.953 & 0.953_{94} \text { to } 0.974_{90} \\ \text { Return on assets } & 0.996 & 0.992 & 0.992 & 0.992 & 0.996 & 0.992_{91: 92: 93} \text { to } 0.996_{90: 94} \\ \text { Return on capital employed } & 0.972 & 0.975 & 0.977 & 0.969 & 0.966 & 0.966_{94} \text { to } 0.977_{92} \\ \text { Asset turnover } & 0.987 & 0.988 & 0.992 & 0.992 & 0.992 & 0.987_{90} \text { to } 0.992_{92: 9394} \\ \text { Interest cover } & 0.947 & 0.932 & 0.923 & 0.924 & 0.934 & 0.923_{92} \text { to } 0.947_{90} \\ \text { Gearing } & 0.901 & 0.925 & 0.918 & 0.880 & 0.826 & 0.826_{94} \text { to } 0.925_{91} \\ \text { Gearing }_{\text {ILw }} & 0.708 & 0.713 & 0.625 & 0.603 & 0.638 & 0.603_{93} \text { to } 0.713_{91} \\ \text { Gearing }_{\text {net debt to equity }} & 0.892 & 0.880 & 0.839 & 0.810 & 0.857 & 0.810_{93} \text { to } 0.892_{90}\end{array}$

Notes: 1. See Table 5 for definitions.

2. Subscripts indicate year(s) in which observation occurred

really matters is whether the position of companies relative to each other (i.e., company rankings) is affected (Foster, 1986: 150-151). ${ }^{14}$ The Spearman rank correlation coefficients between the pre- and post-capitalisation ratios are reported in Table 9. Across the sample as a whole, the four lowest correlations relate to gearing (interest cover plus the three debt/equity measures), the lowest being 0.638 for Ashton's (1985) definition of gearing. ${ }^{15}$ Thus, gearing ratio correlations can be described as only 'moderate'. ${ }^{16}$

Turning to industry groups, the rank correlations for the services sector were, not surprisingly, the lowest among the five sectors, for all nine ratios, the margin of difference being greatest for the three gearing measures. This finding can be explained by both the overall magnitude of leasing undertaken by companies in this sector and the great variation in leasing levels (the sector includes retailers, hotels, media agencies, and vehicle distributors).

\subsection{Inter-temporal stability}

To assess the stability of our findings over time, we repeated the above analysis for the four years 1990 to 1993 , inclusive. This period was selected because, in combination with 1994, it encompasses the latest recession and subsequent recovery. The

\footnotetext{
${ }^{14}$ For example, in a loan appraisal, key ratios may be judged against benchmark measures, thus the absolute value of the ratio is relevant, whereas for investors and investment analysts, relative performance measures are of primary relevance.

${ }^{15}$ Ashton himself reported a rank correlation of 0.90 for this ratio (1985: 237). Possible reasons for the greater impact observed in the present study, discussed in the present paper, relate to the sample and lease type studied.

${ }^{16}$ Pearson product-moment correlation coefficients (not reported here) were substantially lower than the rank correlations for the four gearing-related measures and generally marginally higher for the other ratios.
}

results for the combined industry groups for the period 1990 to 1994 are shown in Tables 10 and 11. The impact of operating lease capitalisation on the magnitude of the nine ratios, and consequent company rankings, is generally very stable over time. Close inspection does, however, reveal that the largest mean differences, and the lowest rank correlations, between pre- and post-capitalisation ratios occurred in the early part of the period. The largest difference was in 1990 for three ratios and in 1991 for a further two ratios, while the lowest correlations were in 1990 for five ratios and in 1991 for a further two ratios. It would appear that operating lease capitalisation had the greatest impact during the trough of the recession, when corporate performance was generally poor and gearing (including operating leasing) was high.

\subsection{Sensitivity analysis}

The sensitivity of the results to key assumptions made (especially the interest rate and estimated lease lives), was investigated using the data for 1994. First, the base assumption of a $10 \%$ interest rate was varied by $\pm 2 \%$. The impact upon the magnitude of the nine ratios, and consequent company rankings, is summarised in Table 12 , columns $2-5$. There is clearly very little change in the results. Significance levels remain unaffected (with the exception of return on capital employed, which becomes significant at the $5 \%$ level at the $8 \%$ interest rate) and the maximum absolute change in rank correlation coefficients is only 0.019 (the correlation coefficient for Ashton's measure of gearing falls from 0.638 (at $10 \%$ interest rate) to 0.619 (at the $8 \%$ interest rate)).

Second, we replaced the base estimates for remaining and total lease lives with two sets of more extreme estimates. One set generally places the leases at a much earlier stage of a shorter total life, 


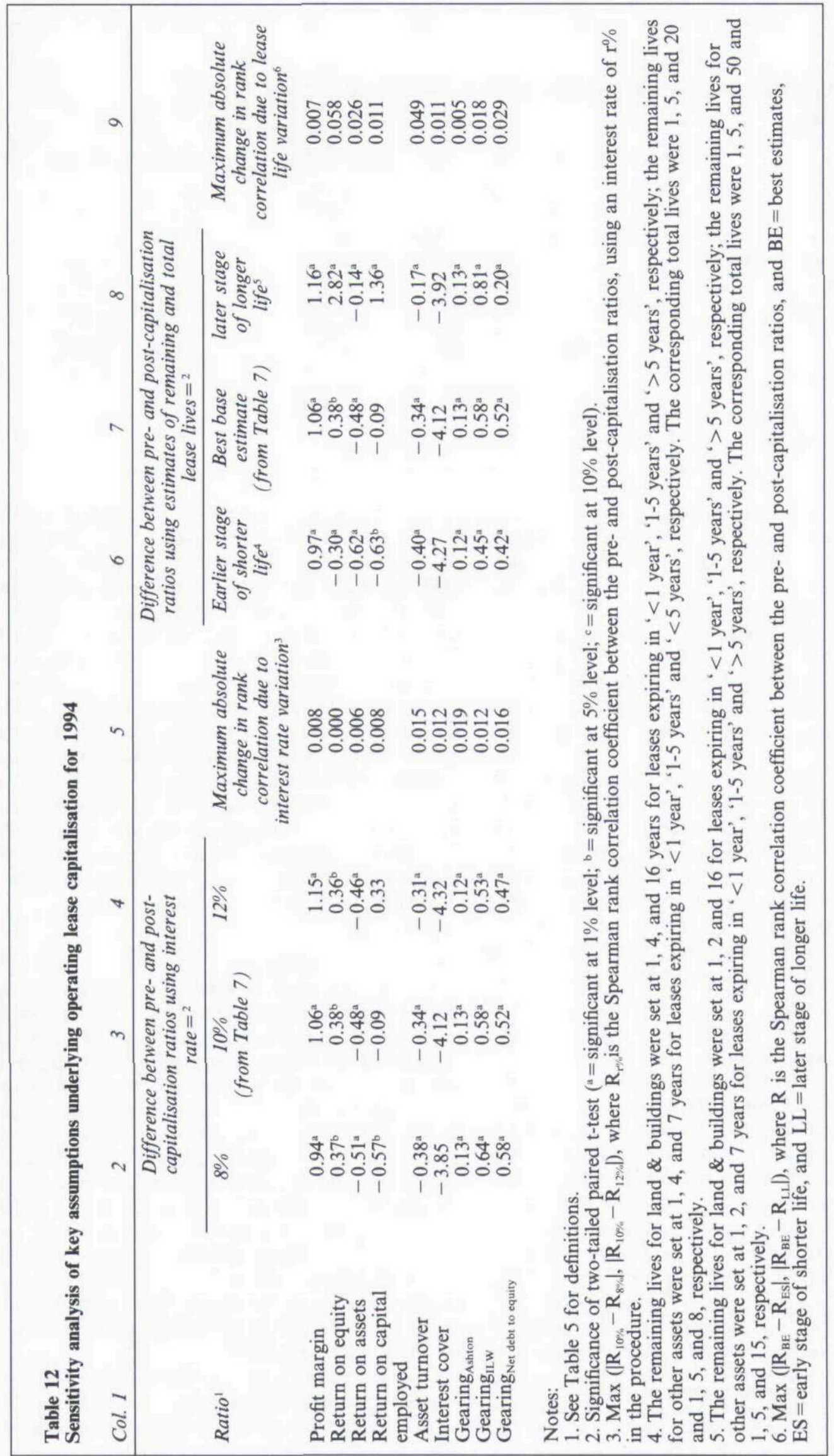


while the other generally places the leases at a much later stage of a longer total life. The impact of these alternative scenarios is summarised in Table 12, columns 6-9. The mean change in return on assets, return on capital employed, return on equity, ILW's measure of gearing, and net debt to equity is marked, especially under the later stages of a longer lease life scenario. However, significance levels remain unaffected (with the exception of return on equity and return on capital employed, which both increase in significance under each of the alternative scenarios). Supplementary analysis indicated the presence of a few extreme observations which were unduly influencing the calculated mean change in selected ratios. Only one ratio showed a maximum absolute change in rank correlation coefficient in excess of 0.05 , and this was return on equity, which fell from 0.996 for the best estimate to 0.938 under the second alternative scenario. This sensitivity analysis suggests that the general results of this study are robust with respect to the key assumptions incorporated in the operating lease capitalisation procedure.

\section{Summary and conclusions}

Under current international lease accounting regulation, leases classified as operating leases do not have to be shown in the balance sheet. Following FRS 5, this situation is likely to change in the UK. This study reports the first large-scale analysis of the impact which the constructive capitalisation of operating leases has on nine key financial ratios used by investment analysts and other users, and also used in financial contracts.

The method of constructive capitalisation developed by ILW (1991) is refined to reflect more accurately individual companies' leasing profiles. Company-specific estimates of remaining and total lease lives, and effective tax rate, are incorporated, and the method distinguishes between asset categories. Application of this method to a randomly selected sample of 232 UK listed companies for 1994 demonstrated that operating leases represent a major source of long-term financing.

On average, the unrecorded long-term liability represented $39 \%$ of reported long-term debt, while the unrecorded asset was $6 \%$ of total assets. Capitalisation was shown to have a significant impact (at the $1 \%$ level) on the profit margin, return on assets, asset turnover, and the three measures of gearing. The rank correlation between pre- and post-capitalisation ratios revealed that company rankings changed markedly for gearing measures. Inter-industry analysis showed that the magnitude of ratio changes and the associated correlation of company rankings produced by operating lease capitalisation was greatest in the services sector, which has the highest value of operating leasing per company and represents diverse company activities.

The capitalisation procedure used is limited by the availability of public domain data and does involve elements of subjectivity. However, findings were shown to be relatively stable across the fiveyear period from 1990 to 1994, although the magnitude of the impact of capitalisation appeared to be linked to the stage in the economic cycle. Findings were also shown to be robust with respect to the key assumptions of the capitalisation method used.

The potential economic consequences of a change in lease accounting regulation are extensive. Prior empirical studies indicate that a wide variety of individual users' decisions, market valuations, company cash flows, and managers' behaviour may all be affected by such a change. This paper provides systematic evidence of the magnitude of the impact of operating lease capitalisation on key financial issues. This can be expected to assist policy-makers in assessing the likely economic consequences of a change in lease regulation.

\section{References}

APB (1973). Disclosure of lease commitments by lessees, Opinion 31. New York: Accounting Principles Board.

ASB (1994). Reporting the substance of transactions, Financial Reporting Standard No. 5. London: Accounting Standards Board.

ASC (1981). Accounting for leases and hire purchase contracts, Exposure Draft 29. London: Accounting Standards Committee.

ASC (1984). Accounting for leases and hire purchase contracts, Statement of Standard Accounting Practice No. 21. London: Accounting Standards Committee.

Arnold, J. and Moizer, P. (1984). 'A survey of the methods used by UK investment analysts to appraise investments in ordinary shares'. Accounting and Business Research, 14, (Summer): 195-207.

Ashton, R. K. (1985). 'Accounting for finance leases: a field test'. Accounting and Business Research, 15 (Summer): 233-238.

Barnes, P. (1987). 'The analysis and use of financial ratios: a review article'. Journal of Business Finance and Accounting, 14 (4) (Winter): 449-461.

Bouwman, M. J., Frishkoff, P. A. and Frishkoff, P. (1987). 'How do financial analysts make decisions? a process model of the investment screening decision'. Accounting Organizations and Society, No. 1: 1-29.

Breton, G. and Taffler, R. J. (1995). 'Creative accounting and investment analyst response'. Accounting and Business Research, 25 (98): 81-92.

Brown, S. J., Goetzmann, W., Ibbotson, R. G. and Ross, S. A. (1992). 'Survivorship bias in performance studies'. Review of Financial Studies, 5 (4): 553-580.

Citron, D. (1992). 'Accounting measurement rules in UK bank loan contracts'. Accounting and Business Research, 23 (89): 21-30.

Cohen, J. B., Zinbarg, E. D. and Zeikel, A. (1987). Investment Analysis and Portfolio Management. 5th ed. Homewood: Irwin.

Company Reporting (1995). 'Reporting the substance of transactions'. No. 62 (August): 3-8. 
FASB (1976). Accounting for Leases. Statement of Financial Accounting Standards No. 13. Stamford, CT: Financial Accounting Standards Board.

Finance and Leasing Association, Annual Report, (1994), (1993), (1992).

Foster, G. (1986). Financial Statement Analysis. 2nd ed. Englewood Cliffs, NJ. Prentice-Hall International.

Garrod, N. (1989). 'Regulation and response: the case of lease disclosure in the UK'. Research in Accounting Regulation, 3: 69-92.

Gibson, C. (1983). 'Financial ratios as perceived by commercial loan officers'. Akron Business and Economic Review, (Summer): 23-27.

Holmes, G. and Sugden, A. (1995). Interpreting Company Reports and Accounts. 5th ed., Cambridge: Woodhead Faulkner. IASC (1982). Accounting for Leases, International Accounting Standard No. 17. London: International Accounting Standards Committee.

ICAEW (1987). Implementation of SSAP 21, Technical Release 664. London: Institute of Chartered Accountants in England and Wales.

Imhoff, E. A., Lipe, R. C. and Wright, D. W. (1991). 'Operating leases: impact of constructive capitalization'. Accounting Horizons, 5 (1): 51-63.
Imhoff, E. A., Lipe, R. C. and Wright, D. W. (1997). 'Operating leases: income effects of constructive capitalization'. Accounting Horizons, 11 (2): 12-32.

Loveday, G. (1995). 'Leasing', pp. 15-28 in Financial Reporting 1994-95: A Survey of UK Reporting Practice, Tonkin, D. J. and Skerratt, L. C. L. (eds.). Milton Keynes: Institute of Chartered Accountants in England and Wales.

McGregor, W. (1996). Accounting for Leases: A New Approach. Financial Accounting Standards Board.

Nelson, A. J. (1963). 'Capitalising leases - the effect on financial ratios'. Journal of Accountancy, (July): 49-58.

Rees, B. (1995). Financial Analysis, 2nd ed. Hemel Hempstead, Herts: Prentice-Hall International.

Schipper, K. (1994). 'Academic accounting research and the standard-setting process'. Accounting Horizons, 8 (4) (December): $61-73$.

SEC (1973). Notice of Adoption of Amendments to Regulation Requiring Improved Disclosure of Rules, Accounting Series Release no. 147. Washington, DC: Securities and Exchange Commission.

Taylor, P. and Turley, S. (1985). 'The views of management on accounting for leases'. Accounting and Business Research, 16 (Winter): 59-67. 
Copyright of Accounting \& Business Research is the property of Croner.CCH Group Limited and its content may not be copied or emailed to multiple sites or posted to a listserv without the copyright holder's express written permission. However, users may print, download, or email articles for individual use. 